\title{
An Urban Myth? \\ New Evidence on Equity, Adequacy and the Efficiency of Educational Resources
}

\author{
Matthew P. Steinberg \\ Assistant Professor of Education \\ Graduate School of Education \\ University of Pennsylvania \\ 3700 Walnut Street, Office 408 \\ Philadelphia, PA 19104 \\ Email: steima@gse.upenn.edu \\ Phone: (215) 898-9336
}

\author{
Rand Quinn \\ Assistant Professor of Education \\ Graduate School of Education \\ University of Pennsylvania \\ 3700 Walnut Street, Office 407 \\ Philadelphia, PA 19104 \\ Email: raq@gse.upenn.edu \\ Phone: (215) 898-9330
}

December 21, 2014

The authors thank Vivian Gadsden, James Lytle, Allan Odden and Janine Remillard for helpful comments on earlier versions of this paper, and Thomas Szczesny and Catherine McManus for able research assistance. Steinberg (corresponding author) can be contacted at steima@gse.upenn.edu; Quinn can be contacted at raq@gse.upenn.edu. 
Equity, Adequacy and Efficiency in Pennsylvania School Finance

\begin{abstract}
In this article, we offer an empirical rejoinder to the oft-told story that large urban districts, like Philadelphia, are inefficient. We situate our study during the very short period in Pennsylvania's recent history when efforts were dedicated to addressing the inequitable distribution of resources through a fair funding formula and to increasing the amount of resources available for education spending. Even in the presence of a funding formula, school districts like Philadelphia (SDP) with its large percentage of low-income students and English language learners were disproportionately burdened. Unsurprisingly, the SDP, like many districts across the nation, did not receive sufficient resources to educate its students. However, we find that contrary to conventional wisdom, SDP did more per pupil with the resources at its disposal than the average peer district in terms of student poverty and achievement.
\end{abstract}


Equity, Adequacy and Efficiency in Pennsylvania School Finance

\section{Introduction}

Debates on the organization of schooling in large urban districts often gravitate toward the perennial issue of financial resources and academic performance. In Chicago, New Orleans, Oakland, Philadelphia, and elsewhere, arguments that schools are failing to meet the academic needs of students are commonplace. Much of the rhetoric ties underperformance to the underutilization of resources. Large urban districts, the story goes, spend more money per pupil but generate lower than expected results when compared to small districts, suburban districts, and charter systems. Large urban districts are inefficient. They lack fiscal discipline. They are burdened by bureaucracy. For example, the Broad Foundationone of the largest philanthropic sources of education funding in the U.S. — argues that "the education crisis" is due, in part, to the fact that "bureaucratic systems, policies and practices that have been built up over decades in inner-city school districts have often led to fewer resources that actually reach the classroom." These inefficiencies range from unfavorable contracts with vendors to duplicative administrative roles, to a general lack of expense monitoring (Broad Foundation, 2014), and suggest that greater efficiencies could be realized in the absence of large, urban bureaucracies.

Perceived inefficiencies have led to calls for greater fiscal transparency. Recent federal education reform efforts have demanded that states and districts provide a clear picture of how, exactly, taxpayer money is used to support public 
education. The Race to the Top District competition, for example, requires applicant school districts to demonstrate "evidence of a high level of 'transparency' in LEA processes, practices, and investments, including making public by school, actual school-level expenditures for regular K-12 instruction, instructional support, pupil support, and school administration" (U.S. Department of Education, 2013).

The perceived inefficiency of large urban districts is rooted within broader and long-standing debates on how and in what ways money matters in education. Although some have argued that there is no systemic relationship between school expenditures and student performance (e.g., Hanushek, 1997), others have found the opposite (e.g., Greenwald et al., 1996; Hedges et al., 1994). Recent scholarship assessing the causal effects of district resources show that additional resources can improve student performance (Guryan, 2001; Papke, 2005; Kreisman \& Steinberg, 2014). On the issue of how money is spent, there is an emerging consensus that proven, effective programs and strategies can have a discernible impact on student outcomes. Policies and programs ranging from class size reduction to extended learning time to Head Start provide the additional opportunities and supports often necessary for disadvantaged students to improve their educational chances (Greenwald et al., 1996; Gibbs, Ludwig, \& Miller, 2011; Jepsen \& Rivkin, 2009; Krueger, 1999; Odden, Picus, \& Goetz 2010; Rebell, 2006; Rebell \& Wardenski, 2004). The question is no longer whether money makes a difference for students but rather (a) the extent to which educational resources are adequate for schools to 
educate their students and (b) the ways in which educational resources are distributed to and utilized by districts serving different student populations in different geographic contexts.

In this article, we first begin by discussing the evolving historical, legal and policy contexts that have framed the contemporary debate on the equitable and adequate distribution of education resources. This discussion serves as a backdrop for a closer assessment of these issues as they relate to the role of funding in states with large urban school districts. We situate our study during the very short period in Pennsylvania's recent history when efforts were dedicated to addressing the inequitable distribution of resources through a fair funding formula and to increasing the amount of resources available for education spending through a gradual increase in state appropriations. We offer empirical evidence on the extent to which education spending in districts across Pennsylvania is both inadequate for all students to achieve academically and is distributed in such a way that disadvantages some districts while benefitting others. We then offer an empirical rejoinder to the oft-told story that large urban districts, like the School District of Philadelphia (SDP), are inefficient. Even in the presence of a funding formula, districts like Philadelphia with its large percentage of low-income students and English language learners were disproportionately burdened. Unsurprisingly, the SDP, like many districts across the nation, did not receive sufficient resources to educate its students. However, we find that contrary to conventional wisdom, SDP did more per pupil 
Equity, Adequacy and Efficiency in Pennsylvania School Finance

with the resources at its disposal than the average peer district in terms of student poverty and achievement.

\section{Equity \& Adequacy in Education Financing}

Equity in education finance refers to the fair distribution of available resources to students across school districts. Three forms of equity are commonly understood. Horizontal equity conceptualizes all students as equivalents, leading to uniform per-pupil spending throughout a system. In contrast, vertical equity takes into account student characteristics associated with increased need, leading to (appropriately) unequal funding. A third principle of equity, fiscal neutrality (or equal opportunity), stipulates a decoupling of educational expenditures from district wealth or tax effort (Berne and Stiefel 1984).

By contrast, adequacy refers to the distribution of resources such that all students, regardless of characteristics, have an equal opportunity to achieve academically. Adequacy claims acknowledge that educational needs vary across students. English-language learners (ELLs), students living in poverty, and special education students, for example, all require a larger investment than other students in order to achieve academically. This means that districts with high numbers of highneed students require more funding (Baker \& Welner, 2011; Baker \& Corcoran, 2012; Buzuvis, 2001; Hanushek \& Lindseth, 2009; Springer, Liu, \& Guthrie, 2009; Superfine, 2010). 
Legal mobilization to alter state education finance systems on first equity and then adequacy grounds proliferated in the decades following Brown. In 1971, the California Supreme Court determined that the state's public school financing system was in violation of the equal protection clause of the Fourteenth Amendment of the U.S. Constitution. At the time, over 55 percent of California's educational revenue came from local property taxes. Although the state had in place a modest program of equalization and supplemental funding, significant disparities across school districts remained. "This funding scheme invidiously discriminates against the poor because it makes the quality of a child's education a function of the wealth of his [sic] parents and neighbors," argued the Court. "Recognizing as we must that the right to an education in our public schools is a fundamental interest which cannot be conditioned on wealth, we can discern no compelling state purpose necessitating the present method of financing" (Serrano v. Priest at 588). There were two parts to the Court's decision: public education was a fundamental right, and inter-district property tax disparities meant that California's system of school financing discriminated on the basis of wealth. The ruling encouraged finance reform advocates in other states to initiate similar equity-based lawsuits built on the constitutional guarantee of equal protection (Enrich, 1995; Hanushek \& Lindseth, 2009; Superfine, 2010).

This early wave of legal action was short-lived. In 1973, the U.S. Supreme Court considered a school equity appeal originating from Texas. As was the case in 
California (and in other states), public education in Texas was financed through local property taxes to a degree sufficient to create significant disparities across school districts. Departing from Serrano, the Court determined that education was not a fundamental right and that the Texas system, despite its wealth disparities, was not unconstitutional (San Antonio v. Rodriguez at 37). This ruling ended efforts to equalize inter-district spending through the Fourteenth Amendment. As a result, subsequent legal action took a narrowed focus on state constitutional provisions for equal protection (Hanushek \& Lindseth, 2009). As a whole, post-Rodriquez legal action was marginally successful, with complainants winning only 7 of 23 court cases from 1973 to 1988 (Enrich, 1995; Superfine, 2010).

In time, advocates began bolstering their claims by leveraging state constitutional provisions for education in addition to state equal protection requirements. This strategy precipitated the shift to adequacy-based arguments by allowing plaintiffs to argue that education is a fundamental right requiring a sufficient level of state support for student achievement (Enrich, 1995; Hanushek \& Lindseth, 2009; Springer et al., 2009). The bellwether case in this regard is Rose v. Council for Better Education, Inc. (1989), in which the Kentucky Supreme Court delineated factors constituting educational adequacy that many states have since adopted for their own adequacy tests (Buzuvis, 2001; Enrich, 1995).

In addition to Rose, the standards and accountability movement in education policy facilitated recent adequacy-based approaches to educational finance reform 
(Superfine, 2010). By the late 1990s, several states mandated curricular standards and annual tests to measure student ability. Within a few years, the movement was solidified with the passage of the No Child Left Behind (NCLB) Act in 2002. In prior years, courts had difficulty devising an effective test to measure equity or adequacy (Buzuvis, 2001; Enrich, 1995). This was no longer the case with the development of specific state-level performance standards under NCLB (Rebell, 2006). Furthermore, scholars have gradually refined their methods to accurately measure and assess adequate funding (Rebell, 2006; Odden, et al., 2010). With these various benchmarks as guides, courts now often mandate change in school finance mechanisms while leaving room for legislators and other stakeholders to shape the system ultimately put in place (Superfine, 2010). The post-Rose wave of court cases was comparatively successful, particularly for those cases that occurred in the wake of the standards and accountability movement. Since 1989, state funding systems were overturned for failing to provide adequate education in 20 of the 27 lawsuits that ended with a court ruling, including 10 victories for plaintiffs since 2000 (Odden, Picus, \& Goetz, 2010; Springer et al., 2009).

\section{The Pennsylvania Context}

Pennsylvania has bucked the four-decade trend toward equity and adequacy in school financing. In 1992, the Pennsylvania General Assembly discontinued its use of a fixed formula to determine basic education funding. ${ }^{1}$ As a result, the annual

\footnotetext{
${ }^{1}$ Act of July 9, 1992, P.L. 392, No. 85.
} 
education budget process was conducted without strict guidelines, was based largely on the prior year's appropriation, and was absent of any codified consideration for student enrollment or student needs. In response, lawsuits were filed by the Pennsylvania Association of Rural and Small Schools and on behalf of the city and School District of Philadelphia to ensure a transparent and predictable education appropriation process (PARSS v. Ridge and Marrero v. Commonwealth, respectively). Both lawsuits were ultimately unsuccessful at ending the status quo education budget process. In 1999, the State Supreme Court observed in its dismissal of Marrero that "everything related to the maintenance of a 'thorough and efficient system of public schools,' must at all times be subject to future legislative control," ruling that "it would be impossible to resolve the claims without making an initial policy determination of a kind which is clearly legislative, and not judicial, discretion" (Marrero v. Commonwealth at 25 \& 34). Consequently, by the 2006-2007 school year, "over three-fourths of the total subsidy was based on the system from the early 1990's" that had led to the equity lawsuits (Bissett \& Hillman, 2013, p. 44). In 2007, the Pennsylvania State Board of Education was presented with a study calculating the "basic cost per pupil to provide an education that will permit a student to meet the State's academic standards and assessments" (Augenblick, Pailich, \& Associates, Inc., 2007, p. ii). This "Costing Out" study determined that for the 2005-06 school year, an additional $\$ 4.38$ billion in spending was necessary to meet student achievement targets (total current expenditure for 2005-06 was 
approximately $\$ 18.4$ billion). In line with similar efforts across the nation, the study proposed a base cost $(\$ 8,003$ per student) plus cost weights and additional cost factors resulting in a per student estimate of $\$ 11,926$, compared to an actual per student spending of $\$ 9,512$.

In 2008, the Pennsylvania school code was amended to include language mandating that education funding to districts be based largely on the formula offered by the Costing Out study. In addition, then-Governor Rendell committed to increasing education funding with the goal of closing 50 percent of the identified adequacy gap over six years. Local school districts were expected to close the remaining 50 percent. Initially, state education funding did increase, although much of this was due to federal economic stimulus funds. The effort did not last, however. In 2011, under Governor Tom Corbett, the funding formula requirement to account for student and district characteristics was removed from the school code and the state budget included an overall reduction in basic education funding

Today, Pennsylvania ranks near the bottom in cross-state comparisons of equity and adequacy as there exists large disparities in the way Pennsylvania distributes school funds, including below-average per pupil expenditures, wide funding variations across school districts, and a greater dependency on local revenue streams (Education Law Center, 2013; Baker et al., 2012). ${ }^{1}$ Attention to education financing in Pennsylvania will only intensify in the coming years as legal advocates have recently signaled their intent to file an equity and adequacy lawsuit arguing that 
the Commonwealth has failed to adhere to its constitutional mandate to provide a "thorough and efficient system of public education" (Leach, 2014).

\section{Estimating Adequacy Gaps}

Adequacy-based claims argue that education expenditures must be sufficient to produce acceptable academic outcomes for all students, especially when educational needs vary across students. The difference between the funding that districts need for all students to achieve academically and the amount districts actually spend is called the adequacy gap. To assess the extent of the gap between actual 2009-10 per-pupil spending and the amount of per-pupil spending necessary to ensure that all students meet state performance expectations, we calculated an adequate per-pupil funding amount for each school district in Pennsylvania. Our estimates of the adequacy gap for Pennsylvania districts follows the methodology employed by the Costing Out study, the legislatively commissioned study on school funding in Pennsylvania (Augenblick, Palaich \& Associates, Inc., 2007). For each district with available data, ${ }^{2}$ we calculated the following:

$$
\begin{aligned}
& \text { (1) } \text { Adequate }_{i, 09-10}=\left\{\left(\text { Enroll }_{i}^{*} \text { Enrollment }_{i}{ }^{*} \text { Base }\right)+\left(\text { ELL }_{i}^{*}{ }^{*} \text { ELL_Students }_{i}\right.\right. \\
& \text { *Base })+\left(\text { SpecEd }_{i}^{*} \text { SpecEd_Students }_{i}{ }^{*} \text { Base }\right)+\left(\text { FRPL }_{i}^{*}\right. \text { FRPL_Students } \\
& \text { *Base })+\left(\text { ModEnroll }_{i}^{*} \text { Base }\right)+\left(\text { Gifted }_{i}^{*} \text { Gifted_Students }_{i}^{*} \text { Base }\right)^{*}{ }^{*} \\
& \text { (Geograpby) }
\end{aligned}
$$

where Adequate $_{i, 09-10}$ is the estimated adequate per-pupil spending for district $i$ (in county c) in the $2009-10$ school year, Base, which is equal to $\$ 8,659$, is the inflation- 
adjusted base cost of educating an average student in Pennsylvania to meet state performance expectations. ${ }^{3}$ See Appendix A for a description of the weights and variables included in equation (1).

Our analysis indicates that Pennsylvania required an additional $\$ 3.21$ billion statewide in education funding to account for the difference between current perpupil spending and an educationally adequate level of spending for the 2009-10 school year. ${ }^{4}$ While the average district-level adequacy gap was $\$ 1,559$ per pupil, this statewide average masks significant differences across districts by student poverty, academic performance and geographic location (see Table 1 and 2). For example, for the 25 percent of districts serving the largest percentage of poor students (with, on average, 57 percent of students receiving free or reduced-price lunch), the average adequacy gap in 2009-10 was $\$ 2,146$ per pupil. In contrast, the 25 percent of districts serving the lowest share of poor students (with, on average, 14 percent of students receiving free or reduced-price lunch) had an adequacy gap of, on average, $\$ 442$ per pupil. While these low-poverty districts spent, on average, less per pupil than was necessary for their students to achieve academically, the adequacy gap in these low poverty districts was one-fifth the size of the adequacy gap in the state's highest poverty districts.

$<$ Tables 1 and 2 about here $>$

There are similar disparities when we consider district level student achievement. For the lowest-performing 25 percent of districts (with, on average, 68 
percent of students in grades 3-8 and 11 proficient or advanced on the 2010 math portion of the Pennsylvania System of School Assessment, or PSSA), the average adequacy gap was $\$ 2,137$ per pupil. Among the highest-achieving quartile of districts (with, on average, 88 percent of students advanced or proficient on the 2010 math PSSA), the adequacy gap was, on average, $\$ 638$ per pupil. While these highperforming districts spent less per pupil than necessary for all of their students to achieve academically, the gap in spending was less than one-third the size of the adequacy gap in the lowest-achieving districts. For reading achievement, the differences are even starker. Specifically, for the lowest-performing 25 percent of districts (with, on average, 63 percent of students in grades 3-8 and 11 proficient or advanced on the 2010 reading PSSA), the average adequacy gap was $\$ 2,196$ per pupil, while the highest-achieving quartile of districts (with, on average, 85 percent of students advanced or proficient on the 2010 reading PSSA), had an adequacy gap of, on average, $\$ 538$ per pupil.

These significant disparities across quartiles suggest to us that Pennsylvania has a long way to go to ensure equitable education funding. Equity entails both logic and predictability. From this perspective, a funding scheme that is logical provides funding to districts based on the characteristics of its students and the local labor market and geographic location of the district itself, a system that some describe as vertical equity (Odden \& Picus, 2007). As the Costing Out study recommends, districts that serve a larger share of economically disadvantaged children should receive 
additional resources for each of these students. Moreover, districts that serve a larger share of students requiring additional educational services (such as English language learners) should also receive additional resources to support their instruction. A logical funding scheme would tie these and other relevant student and district characteristics in a way that is also predictable. Specifically, the determinants of education funding (and the distribution of these resources to local school districts) should be generated by a formula that districts can use to predict the amount of education funding they would receive, given the students in which they are serving.

\section{Assessing Equity and Adequacy}

As a simple measure to assess equity and adequacy, consider the ratio of adequacy gap to per-pupil spending for each district in a state (see Table 3). An adequate (and equitable) system would be one in which this "EQ" ratio would be zero for each district in the state-in other words, a system in which no district had an adequacy gap and district spending in every district was equal to the amount necessary to educate all students, given the characteristics of the students a district serves. An adequate but inequitable system would be one in which the EQ ratio is greater than zero for all districts but the EQ ratio would be different for at least one pair of districts. In such a system, each district would have an adequacy surplus, but at least one district would have a greater surplus to spending ratio than at least one other district.

\footnotetext{
$<$ Table 3 about here $>$
} 
An equitable but inadequate system might have been something Pennsylvanians expected following Governor Rendell's efforts to implement a fair funding formula. In such a system, while the EQ ratio would be less than zero for all districts (indicating an adequacy gap for each district), the ratio between a district's adequacy gap and its per-pupil spending would be equal across all districts. Put another way, while the total amount of education spending would be inadequate to meet the state's performance goals, the distribution of those funds would be done in a way that adhered to the state's equity calculation across all districts. This was not the case in Pennsylvania, and we suspect that in no state at no point in time would one find a system that was fully equitable or adequate, or both. Rather, in every state, districts will likely have EQ ratios that vary, and are greater than zero for some districts (reflecting an adequacy surplus) and less than zero for other districts (reflecting an adequacy gap). Such a scenario is captured by Figure 1, which illustrates the distribution of the EQ ratio across Pennsylvania school districts during the 2009-10 school year. Note that the majority of school districts in Pennsylvania have a negative EQ ratio, suggesting that most districts were spending at levels below what would be adequate to produce academic achievement for all students. Moreover, the variability in EQ reflects the extent of inequity in spending across Pennsylvania districts. Therefore, by measuring the distribution of EQ across districts (and comparing across states and across years), the EQ ratio can be used to assess the relative degree of equity and adequacy. 
$<$ Figure 1 about here $>$

\section{The Urban Myth: A View from Philadelphia}

The story we've told thus far, that the lowest-achieving and highest-poverty districts are the ones that have the largest adequacy gap, is important. But it is not particularly surprising given the degree of interdistrict inequity that is commonplace in the United States. In order to better understand the basis of the argument that large urban districts are inefficient, we compared the SDP to other Pennsylvania districts with similar poverty and achievement levels. What we found in this analysis was surprising.

For the 24 highest-poverty Pennsylvania districts (excluding SDP), with, on average, 77 percent of students receiving free or reduced-price lunch, the 2009-10 adequacy gap was, on average, $\$ 2,608$ per student. SDP is also a high poverty district with, coincidentally, 77 percent of students receiving free or reduced-price lunch. ${ }^{5}$ But for SDP, the gap was $\$ 5,478$ - more than twice as large as the average district serving the same share of economically disadvantaged students (see Figure 2). In other words, to provide adequate resources for its students to achieve academically, SDP, with its particular student and district characteristics, required $\$ 2,870$ more per student than the average peer district required. While the EQ ratio for the average high-poverty school district in Pennsylvania was -0.196 , suggesting that these districts would have needed to spend, on average, approximately 20 percent more than would be necessary to educate all students to meet performance expectations, 
the SDP's EQ ratio was -0.480, meaning that it would need to spend 48 percent more in order to meet its performance expectations.

$<$ Figure 2 about here $>$

And yet, in terms of the actual achievement outcomes among peer districts, SDP students performed slightly better in math and reading. Specifically, for the lowest-achieving Pennsylvania districts (excluding SDP), with, on average, 54 percent of students proficient or advanced on the math portion of the 2010 PSSA, the adequacy gap was, on average, $\$ 2,159$ per student. However, while 56 percent of SDP students achieved at proficient or advanced levels in math, the SDP's adequacy gap was 2.5 times as large as these peer districts (see Figure 3). For the lowestachieving Pennsylvania districts (excluding SDP), with, on average, 47 percent of students proficient or advanced on the reading portion of the 2010 PSSA, the adequacy gap was, on average, $\$ 2,344$ per student. However, while 50 percent of SDP students achieved at proficient or advanced levels in reading, the SDP's adequacy gap was approximately 2.3 times as large as these peer districts (see Figure 4).

$<$ Figures 3 and 4 about here $>$

Philadelphia is ground zero for debates about education spending and student performance. Philadelphia is in the midst of an unprecedented crisis that just in the last 18 months led the district to lay off thousands of teachers and support staff, shutter dozens of schools, and borrow $\$ 304$ million to cover its basic operating 
expense. Over the last decade, reformers have pushed for an increase in the number of charter school seats based on the rationale that charter management organizations are more efficient in their delivery of high quality education than the school district. For example, in calling for an increase in high quality—primarily charter school— seats, the Philadelphia School Partnership describes the SDP as a "big bureaucratic system with a lot of facilities and a lot of overhead and a lot of taxpayer dollars tied up in all of that" (Herold, 2012). As charter enrollment in Philadelphia rapidly increases-from 10 percent of total district enrollment in 2003-04 to 32 percent in 2013-14 - policymakers, reformers, and education observers often make note of the inefficiencies related to the SDP bureaucracy (e.g., Boston Consulting Group, 2012).

However, our findings offer something unexpected, given the conventional wisdom about large urban districts. Philadelphia is, in essence, doing more with less, when compared to its peer high-poverty and low-achieving districts. For Pennsylvania's 24 highest poverty districts (with almost identical achievement levels as the SDP), actual education spending amounted to approximately $\$ 1,000$ per 3.8 proficiency points on the 2010 PSSA reading exam. But for the SDP, actual education spending amounted to approximately $\$ 1,000$ per 4.4 proficiency points on the 2010 PSSA reading exam, a 15 percent difference between SDP and its average peer districts. ${ }^{6}$

\section{Conclusion}


In this paper, we present new evidence on the distribution of educational funding in Pennsylvania, and the extent to which the equitable and adequate distribution of resources is shaped by the students that districts serve. We introduce a simple, policy-relevant measure- EQ - which captures the extent of cross-district inequality and inadequacy in educational spending. We then show that the SDP, contrary to the notion that large urban school districts are inefficiently utilizing their existing resources, actually does more for it students with fewer resources than peer districts.

Of course, the fact remains that neither the SDP nor its peer districts are even close to adequate levels of achievement. In these districts, only about half of the students are proficient or advanced in math and reading, and therefore have quite a long way to go to produce the achievement outcomes we hope and expect for our youth. But we see the situation as a story of possibility more than anything else. If SDP (and other districts, for that matter) are provided an adequate level of resources to educate its students, there's no reason to think that states wouldn't make great strides in improving the academic achievement for all of their students.

The challenges confronting SDP are considerable but not unique. Like SDP, many large urban districts across the country are faced with the perennial issues of declining enrollment, increasing charter competition, aging school buildings, unacceptable student achievement rates, and budgetary constraints. While this paper has offered an empirical response to the familiar claim that large urban districts are 
inefficient, a claim often made in the absence of evidence, more work is necessary to understand the factors which may generate district-level efficiencies in large urban districts. Specifically, a deeper understanding of resource heterogeneity across schools - the extent of intradistrict variation in education spending and academic outcomes - is necessary to reveal the conditions that enable large urban districts to utilize resources in ways that more efficiently produce student achievement outcomes.

We close by suggesting questions future research might address. First, are large urban districts able to leverage scale efficiencies in the selection and implementation of educational programs and practices to generate better educational outcomes with fewer economic resources? Second, do large urban districts tend to better utilize intervention programs and strategies that increase student achievement among traditionally disadvantaged populations? Third, do the social and cultural characteristics of large cities attract the type of human capital (for example, higher quality teachers, more able school and district leaders) to urban school districts that may be able to do more with less while serving a larger proportion of disadvantaged students? Although unpacking the idiosyncratic as well as common features of large urban districts that generate efficiency gains in producing student outcomes remains to be done, our findings challenge the notion that SDP is less efficient than its peer districts. And our findings suggest an argument in favor of maintaining large urban districts as opposed to dismantling them. 


\section{Notes}

1. The issue of cross-state rankings and comparisons of equitable education funding systems is contested. For an alternate view that places Pennsylvania in the top third of states, see Education Week Research Center. "Quality Counts 2014: District Disruption and Revival.” Editorial Projects in Education. Bethesda, MD. January 2014.

2. Of the 500 Pennsylvania school districts, data was available to generate an estimate of the adequacy gap for 491 districts.

3. We set the Base cost to equal (in real 2010\$) the base cost estimate from the PA Study, which was $\$ 8,003$ for the 2005-06 school year. (Augenblick, Palaich \& Associates, Inc., 2007). The Base cost excludes food service costs, transportation costs, costs associated with community services, adult education, capital costs (such as school building construction), and debt service costs.

4. The $\$ 3.21$ billion represents the total adequacy gap for 491 (of the 500 ) noncharter school districts in PA with available data for the 2009-10 school year. We generate the statewide adequacy gap in two steps: first, we calculate the districtlevel adequacy gap (surplus) by multiplying the district-specific per pupil adequacy gap (surplus) by the district's total student enrollment; second, we sum the district-level adequacy gap (surplus) across the 491 districts. Of the 491 districts, 79 districts had an adequacy surplus, and 412 districts had an adequacy gap. If we focus only on the 412 districts with an adequacy gap in spending, the total adequacy gap statewide rises to $\$ 3.55$ billion. Not surprisingly, the SDP had the largest adequacy gap, totaling $\$ 908$ million. These 491 school districts enrolled 1,651,543 (of the 1,682,891) non-charter school students in Pennsylvania during the 2009-10 school year, which included all prekindergarten, kindergarten, and grades 1-12 students. In 2009-10, there were 1,785,993 students, including charter school students, enrolled in PA public schools (Source: US Department of Education, Common Core of Data).

5. The 24 highest-poverty districts in PA were comparable with the SDP on more than just the share of students receiving free or reduced-price lunch. While 56 and 50 percent of SDP students were proficient in math and reading, respectively, on the 2010 PSSA, on average, 57 and 50 percent of students in the 24 highest-poverty districts were proficient in math and reading, respectively, on the 2010 PSSA. 
6. To calculate the cost associated with district achievement, we calculated the following: $1000^{*}$ (district achievement/per pupil spending), where district achievement is the share of students in grades 3-8 and 11 proficient or advanced on the 2010 PSSA, and per pupil spending is the actual per pupil spending during the 2009-10 school year. For the 2010 PSSA math results, actual spending in the SDP amounted to $\$ 1,000$ per 4.90 proficiency points; in the 24 highest-poverty districts, actual spending amounted to $\$ 1,000$ per 4.28 proficiency points. The SDP generated approximately 14 percent greater achievement, per dollar, than similar districts. 


\section{References}

Augenblick, Palaich, and Associates (APA). (2007). Costing Out the Resources Needed to Meet Pennsylvania's Public Education Goals. Augenblick, Palaich, and Associates, Inc. Denver, CO.

Augenblick, Palaich, and Associates (APA). (2009). Costing Out the Resources Needed to Meet Pennsylvania's Education Goals for Students with Disabilities. Augenblick, Palaich, and Associates, Inc. Denver, CO.

Baker, B., \& Welner, K. (2011).School finance and courts: Does reform matter, and how can we tell? Teachers College Record, 113(11), 2374 - 2414.

Baker, B., \& Corcoran, Sean. (2012). The Stealth Inequities of School Funding. Center for American Progress, Washington, D.C.

Baker, B., Sciarrra, D., \& Farrie, D. (2012). Is School Funding Fair? A National Report Card. Education Law Center. Newark, NJ.

Berne, R., \& Stiefel, L. (1984). The Measurement of Equity in School finance: Conceptual, Methodological, and Empirical Dimensions. Baltimore: Johns Hopkins University Press.

Bissett, J., Hillman, A. (Updated 2013). The History of School Funding in Pennsylvania: 1682 -2013. The Pennsylvania Association of Rural and Small Schools. Harrisburg, PA.

Boston Consulting Group. (2012). Transforming Philadelphia's Public Schools Key findings and recommendations. Retrieved February 20, 2014 from http://webgui.phila.k12.pa.us/uploads/v_/IF/v_IFJYCOr72CBKDpRrGA AQ/BCG-Summary-Findings-and-Recommendations_August_2012.pdf.

Broad Foundation. (2014). 75 Examples of How Bureaucracy Stands in the Way of America's Students and Teachers. Broad Foundation: Los Angeles, CA. Retrieved February 20, 2014 from http://www.broadeducation.org/about/bureaucracy.html.

Buzuvis, Erin. (2001). 'A' for effort: Evaluating recent state education reform in response to judicial demands for equity and adequacy. Cornell Law Review, 86, $644-691$. 
Equity, Adequacy and Efficiency in Pennsylvania School Finance

Coleman, J. S., Campbell, E. Q., Hobson, C. J., McPartland, J., Mood, A. M., Weinfeld, F. D., \& York, R. (1966). Equality of Educational Opportunity. U.S. Government Printing Office: Washington, DC.

Education Law Center. (2013). Funding, Formulas, and Fairness: What Pennsylvania Can Learn From Other States' Education Funding Formulas. Education Law Center. Newark, NJ.

Enrich, Peter. (1995). Leaving equality behind: New directions in school finance reform. Vanderbilt Law Review, 48(1), 100 - 194.

Gibbs, C., Ludwig, J., \& Miller, D. L. (2011). Does Head Start do any lasting good? (No. w17452). National Bureau of Economic Research.

Greenwald, R., Hedges, L., \& Laine, R. (1996). The effect of school resources on student achievement. Review of Educational Research. 66 (3), 361 - 396

Guryan, J. (2001). Does money matter? Regression-discontinuity estimates from education finance reform in Massachusetts (No. w8269). National Bureau of Economic Research.

Hanushek, E. A. (1986). The economics of schooling: Production and efficiency in public schools. Journal of Economic Literature, 24(3), 1141-1177.

Hanushek, E. A. (1989). The impact of differential expenditures on school performance. Educational Researcher, 18(4), 45-62.

Hanushek, E. A. (1997). Assessing the effects of school resources on student performance: An update. Educational Evaluation and Policy Analysis, 19(2), 141 164.

Hanushek, E. A., \& Lindseth, A. A. (2009). Schoolhouses, courthouses, and statehouses: Solving the funding-achievement puzzle in America's public schools. Princeton, NJ: Princeton University Press.

Hedges, L. V., Laine, R. D., \& Greenwald, R. (1994). An exchange: Part I: Does money matter? A meta-analysis of studies of the effects of differential school inputs on student outcomes. Educational researcher, 23(3), 5-14.

Herold, B.(2012)."Great Schools Compact set to reshape city's education landscape" Public School Notebook/WHYY Newsworks. Retrieved February 20, 2014 from http://thenotebook.org/blog/124556/what-philadelphia-schoolpartnerships-role-great-schools-compact. 
Equity, Adequacy and Efficiency in Pennsylvania School Finance

Jepsin, C., \& Rivkin, S. (2009). Class size reduction and student achievement: The potential tradeoff between teacher quality and class size. The Journal of Human Resources, 44(1), 223 - 251

Kreisman, D., \& Steinberg, M. (2014). Does more money affect the allocation of spending and student achievement? Evidence from Texas's small district adjustment. Working paper.

Krueger, A. B. (1999). Experimental estimates of education production functions. The Quarterly Journal of Economics, 114(2), 497-532.

Leach, S. (2014, January 9). "Activists: Education funding debate likely to return to court" Philadelphia Daily News.

Marrero v. Commonwealth, 709A.2d 956, 1998 Pa. Commw. Lexis 144 (1998)

Odden, A. \& Picus, L.O. (2007). School Finance: A Policy Perspective, $4^{\text {th }}$ ed. New York: McGraw Hill.

Odden, A. Picus, L., \& Goetz, M. (2010). A 50-state strategy to achieve school finance adequacy. Educational Policy, 24(4), 628 - 654

Papke, L. E. (2005). The effects of spending on test pass rates: evidence from Michigan. Journal of Public Economics, 89(5), 821-839.

PARSS v. Ridge. File no. 11. M.D. 1991. Pa Commw. (1998)

Rebell, M., \& Wardenski, J. (2004) Of Course Money Matters: Why the Arguments to the Contrary Never Add Up. The Campaign for Fiscal Equity. New York, NY.

Rebell, M. A. (2006). Poverty Meaningful Educational Opportunity, and the Necessary Role of the Courts. NCL Rev., 85, 1467 - 1542.

Rebell, M. (2008) "Equal Opportunity and the Courts" Phi Delta Kappan, 89 (6), 432 439.

San Antonio Independent School Dist. v. Rodriguez, 411 U.S. 1, 93 S. Ct. 1278, 36 L. Ed. 2d 16 (1973).

Rose v. Council for Better Educ., Inc., 790 S.W.2d 186, 60 Ky. 1289 (1989).

Serrano v. Priest, 487 P.2d 1241, 5 Cal. 3d 584, 96 Cal. Rptr. 601 (1971). 
Equity, Adequacy and Efficiency in Pennsylvania School Finance

Springer, M., Liu, K, \& Guthrie, J. (2009). The impact of school finance litigation on resource distribution: A comparison of court-mandated equity and adequacy reforms. Education Economics, 17 (4), 421- 444.

Students First. (2014). "State Policy Report Card 2014." Students First. Sacramento, CA. Retrieved February 20, 2014 from http://report.studentsfirst.org.

Superfine, B. (2010). Court-driven reform and equal educational opportunity: Centralization, decentralization, and the shifting judicial role. Review of Educational Research, 80 (1), 108 - 137.

United States Department of Education. (2013). Proposed Priorities, Requirements, Definitions, and Selection Criteria--Race to the Top-District. Federal Register Volume 78, Number 73 (Tuesday, April 16, 2013), Document Number 2013-08847. Retrieved from www.gpo.gov 
Table 1. Adequacy Gap, by District Characteristics, excluding SDP (SDP Adequacy Gap= $\$ 5,477.92)$

\begin{tabular}{|c|c|c|c|c|}
\hline District Characteristic & Q1 & Q2 & Q3 & Q4 \\
\hline \multirow{5}{*}{ Enrollment } & $-\$ 1470.72$ & $-\$ 1849.27$ & $-\$ 1586.37$ & $-\$ 1291.61$ \\
\hline & $(\$ 1635.85)$ & $(\$ 1426.67)$ & $(\$ 1379.86)$ & $(\$ 2205.59)$ \\
\hline & $\{-\$ 6388.15, \$ 4474.93\}$ & $\{-\$ 4797.30, \$ 2954.13\}$ & $\{-\$ 6247.40, \$ 2659.47\}$ & $\{-\$ 8888.27, \$ 8716.32\}$ \\
\hline & {$[\mathrm{n}=121]$} & {$[\mathrm{n}=124]$} & {$[\mathrm{n}=123]$} & {$[\mathrm{n}=122]$} \\
\hline & $<921.9(266.47)>$ & $<1736.07(262.31)>$ & $<2919.17(462.00)>$ & $<6557.06(3544.56)>$ \\
\hline \multirow{5}{*}{ FRPL } & $-\$ 441.65 * * *$ & $-\$ 1747.82$ & $-\$ 1874.76$ & $-\$ 2146.02$ \\
\hline & $(\$ 1760.98)$ & $(\$ 1209.93)$ & $(\$ 1360.40)$ & $(\$ 1861.40)$ \\
\hline & $\{-\$ 4176.97, \$ 8716.32\}$ & $\{-\$ 4797.30, \$ 2010.38\}$ & $\{-\$ 6247.40, \$ 4474.93\}$ & $\{-\$ 8888.27, \$ 2149.65\}$ \\
\hline & {$[\mathrm{n}=123]$} & {$[\mathrm{n}=122]$} & {$[\mathrm{n}=123]$} & {$[\mathrm{n}=122]$} \\
\hline & $<13.9 \%(5.3 \%)>$ & $<29.0 \%(3.8 \%)>$ & $<39.9 \%(2.7 \%)>$ & $<57.2 \%(12.0 \%)>$ \\
\hline \multirow{5}{*}{ Math Achievement } & $-\$ 2137.11 * * *$ & $-\$ 1830.15$ & $-\$ 1554.82$ & $-\$ 638.32$ \\
\hline & $(\$ 1756.20)$ & $(\$ 1399.58)$ & $(\$ 1411.00)$ & $(\$ 1783.20)$ \\
\hline & $\{-\$ 8888.27, \$ 2149.65\}$ & $\{-\$ 6247.40, \$ 4474.93\}$ & $\{-\$ 4640.36, \$ 4277.82\}$ & $\{-\$ 4176.97, \$ 8716.32\}$ \\
\hline & {$[\mathrm{n}=121]$} & {$[\mathrm{n}=121]$} & {$[\mathrm{n}=124]$} & {$[\mathrm{n}=122]$} \\
\hline & $<67.8 \%(8.3 \%)>$ & $<77.3 \%(1.5 \%)>$ & $<82.2 \%(1.3 \%)>$ & $<88.1 \%(2.4 \%)>$ \\
\hline \multirow{5}{*}{ Reading Achievement } & $-\$ 2195.74 * * *$ & $-\$ 1784.03$ & $-\$ 1639.10$ & $-\$ 537.88$ \\
\hline & $(\$ 1706.54)$ & $(\$ 1192.51)$ & $(\$ 1561.96)$ & $(\$ 1786.32)$ \\
\hline & $\{-\$ 8888.27, \$ 2149.65\}$ & $\{-\$ 5059.97, \$ 1270.44\}$ & $\{-\$ 6247.40, \$ 4474.93\}$ & $\{-\$ 4176.97, \$ 8716.32\}$ \\
\hline & {$[\mathrm{n}=121]$} & {$[\mathrm{n}=123]$} & {$[\mathrm{n}=122]$} & {$[\mathrm{n}=122]$} \\
\hline & $<62.5 \%(9.1 \%)>$ & $<72.4 \%(1.5 \%)>$ & $<77.4 \%(1.6 \%)>$ & $<84.7 \%(3.2 \%)>$ \\
\hline
\end{tabular}

Notes. Author's calculations from data retrieved from the U.S. Department of Education, National Center for Education Statistics, Common Core of Data (CCD) and the Pennsylvania Department of Education (http://www.portal.state.pa.us/portal/server.pt/community/school assessments/7442). The mean adequacy gap for the 2009-10 school year, with standard deviation in parentheses, the minimum and maximum values in brackets and the number of districts in square brackets reported. The mean (standard deviation) of the district characteristic, by quartile, is reported in <brackets $>$. Enrollment includes all pre-kindergarten, kindergarten, and grades 1 12 students enrolled in public (non-charter) schools during the 2009-10 school year. FRPL the proportion of a district's students receiving free or reduced-price lunch during the 2009-10 school year. Math (Reading) Achievement is the proportion of a district's students (in grades 3-8 and 11) proficient or advanced on the math (reading) portion of the 2009-10 Pennsylvania System of School Assessment (PSSA). The mean adequacy gap differs significantly across quartiles, by district characteristic, at the $* 10$ percent, $* * 5$ percent and $* * * 1$ percent levels. 
Table 2. Adequacy Gap, by Geographic Location, excluding SDP (SDP Adequacy Gap= $\$ 5,477.92)$

\begin{tabular}{|c|c|c|c|}
\hline Urban & Suburban & Rural & Town \\
\hline $\begin{array}{c}-\$ 3616.72 * * * \\
(\$ 2900.92) \\
\{-\$ 8888.27, \$ 1768.70\} \\
{[\mathrm{n}=14]}\end{array}$ & $\begin{array}{c}-\$ 1303.03 \\
(\$ 1855.26) \\
\{-\$ 5059.97, \$ 8716.32\} \\
{[\mathrm{n}=206]}\end{array}$ & $\begin{array}{c}-\$ 1489.93 \\
(\$ 1326.76) \\
\{-\$ 4797.30, \$ 4474.93\} \\
{[n=176]}\end{array}$ & $\begin{array}{c}-\$ 1900.86 \\
(\$ 1484.44) \\
\{-\$ 6388.15, \$ 2811.86\} \\
{[n=94]}\end{array}$ \\
\hline
\end{tabular}

Notes. Author's calculations from data retrieved from the U.S. Department of Education, National Center for Education Statistics, Common Core of Data (CCD). The mean adequacy gap for the 2009-10 school year, with standard deviation in parentheses, the minimum and maximum values in brackets and the number of districts in square brackets reported. The mean adequacy gap differs significantly across geographic locations at the $* 10$ percent, $* * 5$ percent and $* * * 1$ percent levels. 
Table 3. EQ as a Measure of Equity and Adequacy

\begin{tabular}{|c|c|c|}
\hline & Adequate & Inadequate \\
\hline \multirow{2}{*}{ Equitable } & $E Q_{i}=0$ for all $i$ districts & $\mathrm{EQ}_{\mathrm{i}}<0$ for all $\mathrm{i}$ districts \\
\hline & & $E Q_{i}=E Q_{j}$ for all i \& j combinations \\
\hline \multirow[b]{2}{*}{ Inequitable } & $E Q_{i}>0$ for all $i$ districts & $E Q_{i}<0$ for all $i$ districts \\
\hline & $\begin{array}{l}\mathrm{EQ}_{\mathrm{i}} \neq \mathrm{EQ}_{\mathrm{j}} \text { for at least one } \mathrm{i} \& \mathrm{j} \\
\text { combination }\end{array}$ & $\begin{array}{l}\mathrm{EQ}_{\mathrm{i}} \neq \mathrm{EQ}_{\mathrm{j}} \text { for at least one } \mathrm{i} \& \mathrm{j} \\
\text { combination }\end{array}$ \\
\hline
\end{tabular}

Notes: $E Q_{i}=$ Adequacy_Gapi $_{i} /$ Per-Pupil_Spending for school district $i$. 
Figure 1. Distribution of EQ Ratio in Pennsylvania, 2009-10

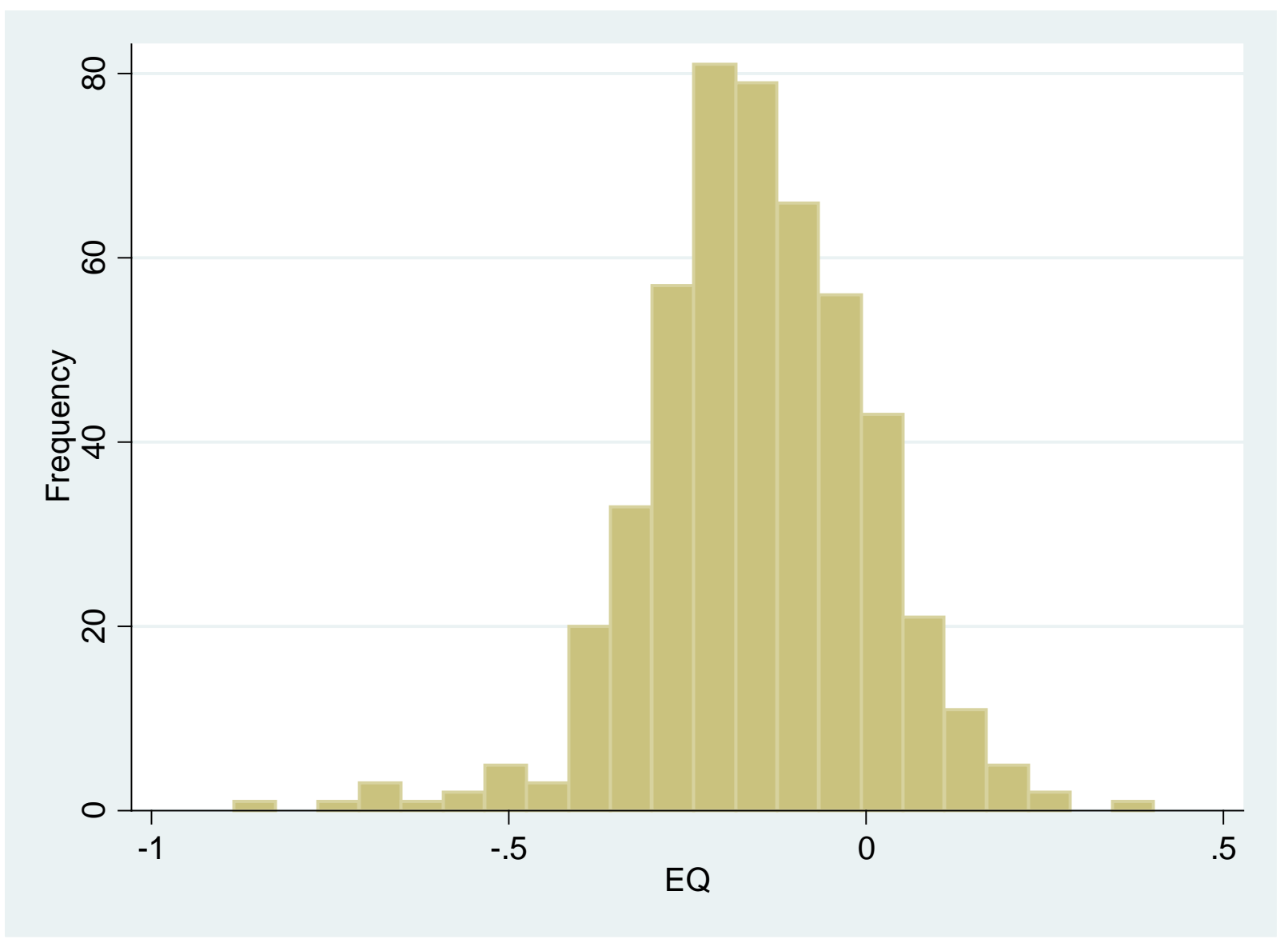

Notes. EQ is the ratio of a district's per pupil adequacy gap (surplus) to its actual per pupil spending during the 2009-10 school year. Districts spending more than would be necessary (e.g. adequacy surplus) to meet performance expectations and assure academic success for all of its students will have positive values of EQ; districts with adequacy gaps will have negative values of EQ. The mean (standard deviation) value of EQ for 491 (of 500) PA districts is -0.153 (0.154), suggesting that, on average, districts would have needed to spend 15 percent more per pupil to educate all students to meet performance expectations. 


\section{Figure 2. Expenditures in SDP and Peer Districts, by District Poverty}

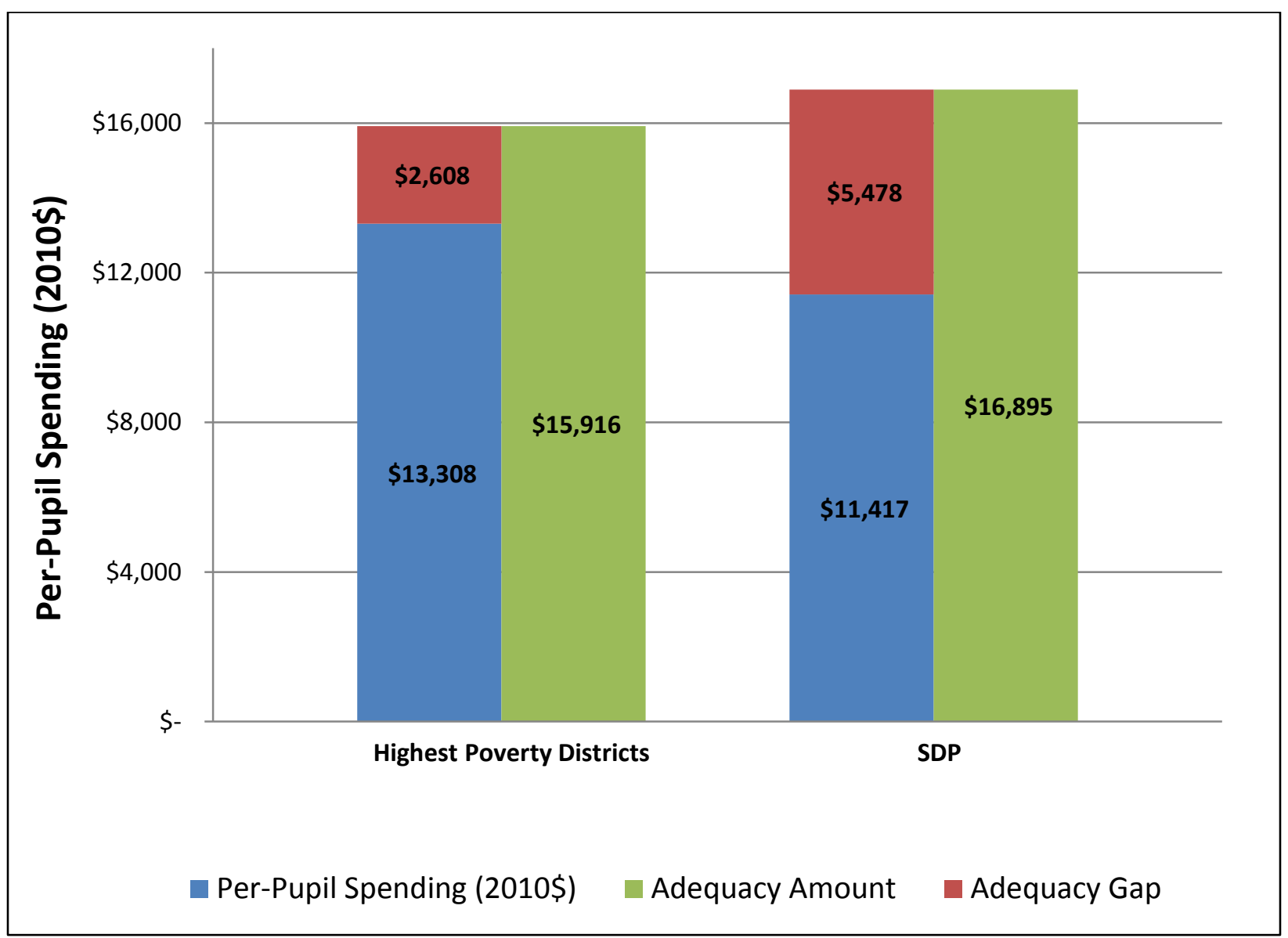

Notes. Authors' calculations from data retrieved from the U.S. Department of Education, National Center for Education Statistics, Common Core of Data (CCD). Data are for the 2009-10 school year. Per-pupil spending is inflation-adjusted and reported in 2010 dollars, and includes instruction, instruction-related, support services, and other elementary/secondary current expenditures, but excludes expenditures on capital outlay, other programs, and interest on long-term debt. The Highest Poverty Districts (excluding the SDP) include the 24 districts serving the largest proportion of students in receipt of free or reduced-price lunch during the 2009-10 school year, with an average FRPL\% of 77 percent. Only nine PA districts served a larger share of students in receipt of free or reduced-price lunch than the SDP (with 77 percent of students in receipt of free or reduced-price lunch) in the 2009-10 school year. 
Figure 3. Expenditures in SDP and Peer Districts, by Math Achievement

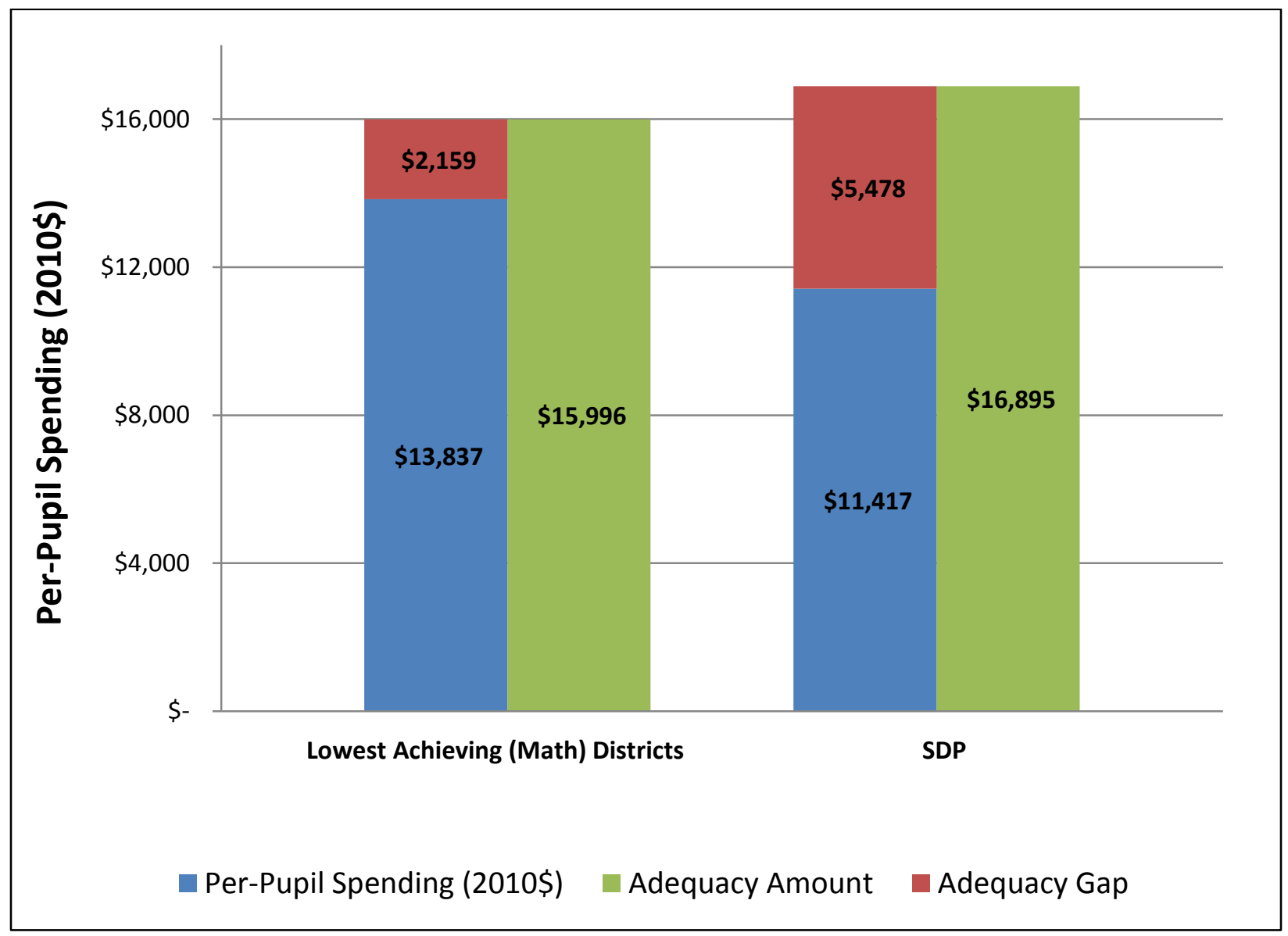

Notes. Authors' calculations from data retrieved from the U.S. Department of Education, National Center for Education Statistics, Common Core of Data (CCD) and the Pennsylvania Department of Education (www.portal.state.pa.us/portal/server.pt/community/school_assessments/7442). Data are for the 2009-10 school year. Per-pupil spending is inflation-adjusted and reported in 2010 dollars, and includes instruction, instruction-related, support services, and other elementary/secondary current expenditures, but excludes expenditures on capital outlay, other programs, and interest on long-term debt. The lowest-achieving districts (excluding the SDP) include the 23 lowest performing districts with, on average, 53.7 percent of students (in grades 3-8 and 11) proficient in math and 46.6 percent in reading (ELA) on the 2009-10 Pennsylvania System of School Assessment (PSSA). In the SDP, 56 percent of students were proficient in math and 50 percent in reading. 
Figure 4. Expenditures in SDP and Peer Districts, by ELA Achievement

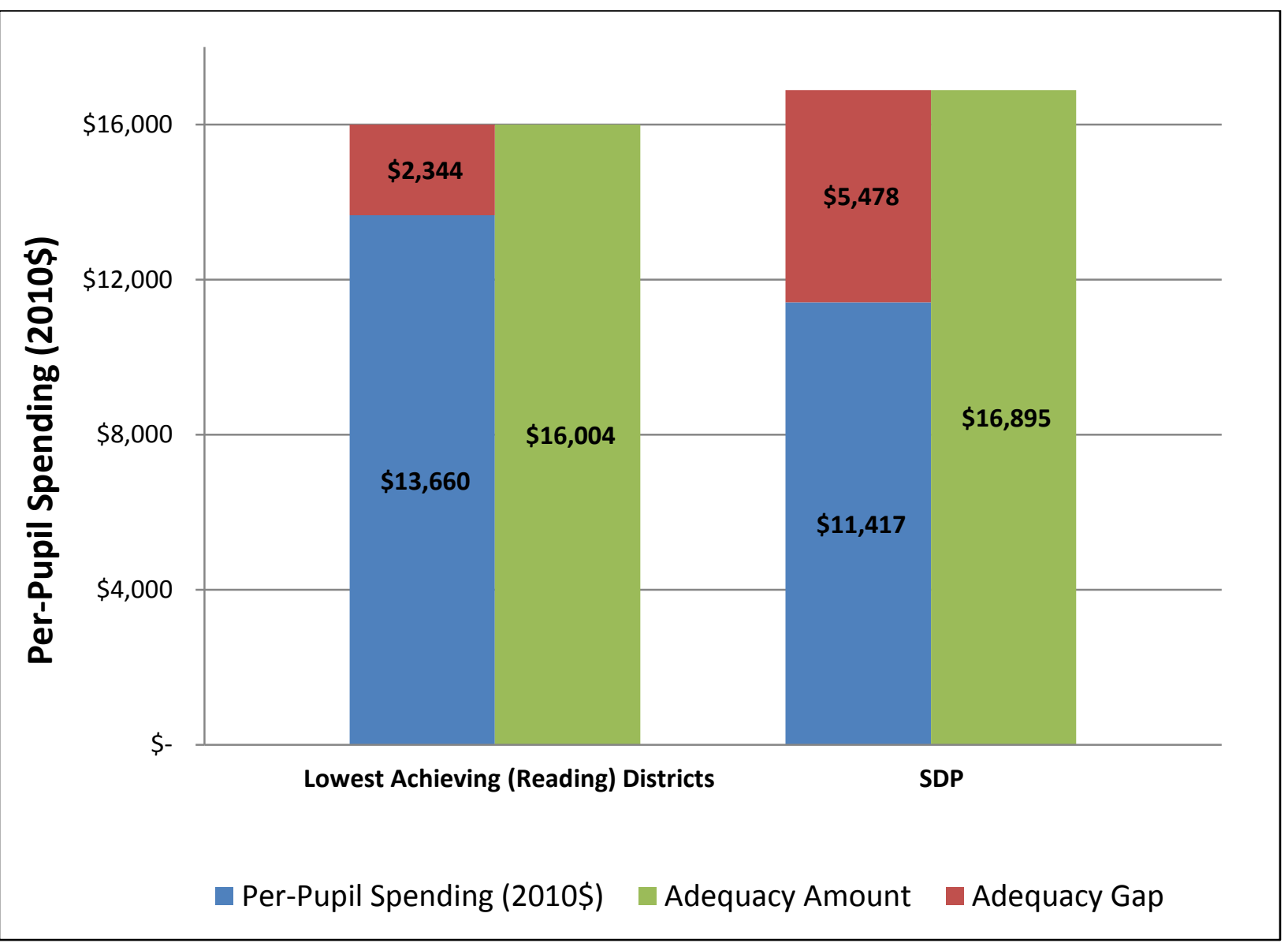

Notes. Authors' calculations from data retrieved from the U.S. Department of Education, National Center for Education Statistics, Common Core of Data (CCD) and the Pennsylvania Department of Education (www.portal.state.pa.us/portal/server.pt/community/school_assessments/7442). Data are for the 2009-10 school year. Per-pupil spending is inflation-adjusted and reported in 2010 dollars, and includes instruction, instruction-related, support services, and other elementary/secondary current expenditures, but excludes expenditures on capital outlay, other programs, and interest on long-term debt. The lowest-achieving districts (excluding the SDP) include the 23 lowest performing districts with, on average, 53.7 percent of students (in grades 3-8 and 11) proficient in math and 46.6 percent in reading (ELA) on the 2009-10 Pennsylvania System of School Assessment (PSSA). In the SDP, 56 percent of students were proficient in math and 50 percent in reading. 


\section{Appendix A. Estimating Adequate Per Pupil Spending}

Following the methodology employed by Augenblick, Palaich \& Associates, Inc., (2007), we summarize the relative weights included in equation (1). For each district, adjustments to the inflation-adjusted base cost were made for district enrollment (both contemporaneous and historical enrollment), the characteristics of the students the district serves (special education, free/reduced-price lunch, English-language learners, academically gifted), and geographic cost differences (at the county level).

First, an enrollment weight (Enroll.) was computed for district $i$ s contemporaneous enrollment. Specifically, Enroll ${ }_{\mathrm{i}}=\max \left\{\left(-0.05^{*}\left(\ln \left(\right.\right.\right.\right.$ Enrollment $\left.\left.\left.\left._{i}\right)\right)+0.483\right), 0\right\}$, where $\ln \left(\right.$ Enrolment $\left._{i}\right)$ is the natural log of district $i$ 's total student enrollment during the 2009-10 school year. Next, we computed a weight $\left(E L L_{i}^{*}\right)$ for the number of English-language learners (ELL_Students $)$ in district $i$ as follows: $E L L_{1}=(-0.023 *$ $\left(\ln \left(\right.\right.$ Enrollment $\left.\left.\left.t_{j}\right)\right)+3.753\right)$, where $E L L_{\mathrm{i}}$ satisfies the following: if $E L L_{\mathrm{i}}<1.48$, then $E L L_{i}^{*}=1.48$; if $E L L_{\mathrm{i}}>2.43$, then $E L L_{\mathrm{i}}^{*}=2.43$; Otherwise, $E L L_{\mathrm{i}}^{*}=E L L_{\mathrm{i}}$. Next, we applied a weight (SpecEd $d_{i}$ ) equal to 1.30 for each special education student $\left(\right.$ SpecEd_Students) in district $i$. We then applied a weight $\left(F R P L_{i}\right)$ equal to 0.43 for each student in receipt of free or reduced-price lunch (FRPL_Students) in district $i$.

Next, we computed a weight $\left(\right.$ Gifted $\left._{i}\right)$ for the number of academically gifted students $\left(\right.$ Gifted_Students $\left._{i}\right)$ in district $i$ as follows: Gifted $_{\mathrm{i}}=0.2 *\left(\right.$ GiftedShare $_{i}^{*}$ Enrollment $\left._{j}\right)$, where GiftedShare $_{i}$ is the proportion of students in district $i$ identified as academically gifted, and Enrollment $t_{i}$ is district $i$ 's total student enrollment during the 2009-10 school year. According to data compiled by the National Association for Gifted Children (http://www.nagc.org/DataMapbyState.aspx), approximately 3.85 percent Pennsylvania's students were identified as academically gifted during the 2012-13 school year. According to the School District of Philadelphia (http://www.phila.k12.pa.us/), 3.12 percent of Philadelphia students were identified as academically gifted during the $2012-13$ school year. Therefore, for all non-SDP districts, we used 3.85 percent as the proportion of academically gifted students (GiftedShare $)$ ); for the SDP, we used the proportion of gifted students in the 2012-13 school year - 3.12 percent - as the share of academically gifted students (GiftedShare $e_{i}$ ) for the 2009-10 school year.

To account for year-to-year fluctuations in district enrollment, we calculated a modified enrollment weight $\left(\right.$ ModEnroll $\left._{i}\right)$ for each district as follows: ModEnroll $_{i}=$ $\left(.03^{*}\right.$ Enrollment $\left._{i, 0506}\right)+\left(.06^{*}\right.$ Enrollment $\left._{i, 0607}\right)+\left(.13^{*}\right.$ Enrollment $\left._{i, 0708}\right)+\left(.26^{*}\right.$ Enrollment $\left.{ }_{i, 0809}\right)+\left(.52^{*}\right.$ Enrollment $\left._{i, 0910}\right)$, where Enrollment ${ }_{i, 0506}$ is district $i$ 's student enrollment during the 2005-06 school year; Enrollment $t_{i, 0607}$ is district $i$ 's student enrollment during the 2006-07 school year; Enrollment, ${ }_{i, 0708}$ is district i's student enrollment during the 2007-08 school year; Enrollment $t_{i, 0809}$ is district $i$ 's student 
enrollment during the 2008-09-06 school year; and Enrollment ${ }_{i, 0910}$ is district i's student enrollment during the 2009-10 school year.

Finally, to account for geographic differences in the cost of living that may affect the cost of delivering educational services, we adjust district-level estimates of adequate spending by a county-level geographic weight (Geography ). The geographic cost of living index does not vary across districts located within county $c$, but does vary across districts located in different counties. 